\title{
Religion and Global Order (cf. Arch. supra. Sandra
} Fancello)

Cardiff, University of Wales Press, 2000, 239 p. (index) (coll. « Religion, Culture and Society ») (cf. Arch. supra, pp. 27-30)

\section{(2) OpenEdition}

\section{Journals}

Édition électronique

URL : http://journals.openedition.org/assr/1386

DOI : $10.4000 /$ assr. 1386

ISSN : $1777-5825$

Éditeur

Éditions de l'EHESS

Édition imprimée

Date de publication : 1 avril 2003

ISBN : 2-222-96732-5

ISSN : 0335-5985

Référence électronique

"Religion and Global Order (cf. Arch. supra. Sandra Fancello) », Archives de sciences sociales des religions [En ligne], 122 | avril - juin 2003, document 122.68, mis en ligne le 10 novembre 2005, consulté le 02 mai 2019. URL : http://journals.openedition.org/assr/1386 ; DOI : 10.4000/assr.1386

Ce document a été généré automatiquement le 2 mai 2019.

Archives de sciences sociales des religions 


\section{Religion and Global Order (cf. Arch. supra. Sandra Fancello)}

Cardiff, University of Wales Press, 2000, 239 p. (index) (coll. « Religion, Culture and Society ») (cf. Arch. supra, pp. 27-30) 